\title{
Factors influencing the soil-plant nitrogen cycle of hill pastures under conventional and organic management
}

\author{
R.L. PARFITT ${ }^{1}$, G.W. YEATES ${ }^{1}$, D.J. ROSS ${ }^{1}$, A.D. MACKAY ${ }^{2}$ and P.J. BUDDING ${ }^{2}$ \\ ${ }^{1}$ Landcare Research, PB 11052, Palmerston North \\ ${ }^{2}$ AgResearch, Grasslands Research Centre, PB 11008, Palmerston North
}

parfittr@LandcareResearch.co.nz

\begin{abstract}
Nitrogen $(\mathrm{N})$ is the major nutrient that limits pasture growth in New Zealand. Here we test the hypothesis that $\mathrm{N}$ supply to herbage from soil microbial mineralization is a function of both the quantity and quality of the soil organic matter, and that this underlying process is similar under conventional and organic management. Preliminary results for OctoberNovember 2002 from nine sites with a wide range of soil $\mathrm{N}$ status at AgResearch, Ballantrae show that microbial-mineralized $\mathrm{N}$ supply from the soil to herbage was the dominant factor controlling the differences in herbage growth. Herbage $\mathrm{N}$ was also highly correlated with the soil $\mathrm{N}$ supply, as estimated from a 56-day laboratory incubation of soil ( $0-7.5$ $\mathrm{cm}$, and $7.5-20 \mathrm{~cm}$ depths). For these soils, spring herbage production could be estimated from the negative relationship with the $\mathrm{C}: \mathrm{N}$ ratio of the topsoils. This suggests the over-riding factor in the $\mathrm{N}$ supply at the nine sites was the quality of soil organic matter in the topsoils. Quality is enhanced through the growth of legumes that in turn depend on the $\mathrm{P}$ status of the soil. The soil parent material at some sites (1996 organic farmlets) is calcareous mudstone, which has a high $\mathrm{P}$ status, and may explain some differences in site fertility not explained by past $\mathrm{P}$ applications. The relationship between the quantity and quality of organic matter and microbial $\mathrm{N}$ mineralization in the four farmlets that had organic management appeared to be on the same trend-lines as those in the conventional farmlets, indicating that the underlying net $\mathrm{N}$ mineralization process was similar under con-
\end{abstract}

ventional and organic management. Other factors statistically related to herbage yield and soil net $\mathrm{N}$ mineralization were some groups of nematodes and microbial $\mathrm{P}$, but not microbial biomass $\mathrm{C}$ or $\mathrm{N}$.

Keywords: $\mathrm{N}$ mineralisation, non-chemical farms, organic farms, soil fertility

\section{Introduction}

Nitrogen $(\mathrm{N})$ is the most important nutrient stored in soil, primarily in soil organic matter from which it is mineralized to ammonium- $\mathrm{N}$ by the action of enzymes, produced by soil organisms. Nitrogen is the nutrient that most limits grass growth. Organic farms rely heavily on soil biological activity to provide nutrients for plants, given the limited options for adding $\mathrm{N}$ (mainly from legume growth). Without the opportunity to add fertiliser- $\mathrm{N}$, organic producers must therefore seek to maintain or enhance soil organic matter to ensure $\mathrm{N}$ supply meets plant needs.

Our approach for assessing factors involved in soil fertility was to measure soil microbial properties and fauna in relation to herbage accumulation. We selected nine sites at Ballantrae where ongoing long-term differential conventional and organic managements had established an ecolo gical gradient (Table 1). Three sites ranged from very low fertility to very high fertility from within a long-term fertiliser and sheepgrazing study (Lambert et al. 2000), two were from within an intensive bull-beef unit (Barker et al. 1999), and four had been under organic management with sheep-grazing for the previous 5 or 15 years (Mackay et al. 1998).

Table 1 Management regimes at the sites, soil C, N, C:N, Olsen- $\mathrm{P}$ and $\mathrm{pH}$ values and net $\mathrm{N}$ mineralization during 56 days, of the soils $(0-7.5 \mathrm{~cm})$ sampled in October 2002.

\begin{tabular}{lcccccc}
\hline Site & $\begin{array}{c}\text { Soil C } \\
(\mathrm{g} / \mathrm{kg})\end{array}$ & $\begin{array}{c}\text { Soil N } \\
(\mathrm{g} / \mathrm{kg})\end{array}$ & $\begin{array}{c}\text { Soil } \\
\text { C:N }\end{array}$ & $\begin{array}{c}\text { Olsen P } \\
(\mathrm{mg} / \mathrm{kg})\end{array}$ & $\mathrm{pH}$ & $\begin{array}{c}\text { Net N mineralization } \\
(\mathrm{mg} / \mathrm{kg})\end{array}$ \\
\hline 1. No P farmlet & 51 & 3.5 & 14.5 & 8 & 6.0 & 24 \\
2. Medium P farmlet & 49 & 3.7 & 13.3 & 15 & 6.0 & 109 \\
3. High P farmlet & 54 & 4.1 & 13.1 & 40 & 5.6 & 98 \\
4. Bulls + N farmlet & 63 & 5.8 & 10.9 & 37 & 5.7 & 338 \\
5. Bulls farmlet & 44 & 3.6 & 12.2 & 13 & 5.6 & 117 \\
6. Organic 1996 low stocked & 55 & 4.9 & 11.1 & 26 & 5.8 & 204 \\
7. Organic 1996 high stocked & 52 & 4.6 & 11.4 & 25 & 5.9 & 211 \\
8. Organic 1985 low stocked & 49 & 3.8 & 13.1 & 11 & 5.7 & 98 \\
9. Organic 1985 high stocked & 42 & 3.3 & 12.7 & 7 & 5.8 & 108 \\
\hline
\end{tabular}


Here we test the hypothesis that $\mathrm{N}$ supply to herbage from soil microbial mineralization is a function of both the quantity and quality of the soil organic matter, and that this underlying process is similar under conventional and organic management. Soil chemical properties that can influence $\mathrm{N}$ supply are also investig ated.

\section{Methods}

Duplicate sets of plots were set out on the same slope $\left(15^{\circ}\right)$ and aspect (north) on each of the nine sites at AgResearch, Ballantrae (Table 1). Two organic system sites were stocked at $7 \mathrm{SU} / \mathrm{ha}$ and two at 11 $\mathrm{SU} / \mathrm{ha}$. We sampled the soils from the 18 plots at two depths $(0-7.5 \mathrm{~cm}$, and $7.5-20 \mathrm{~cm})$ in October 2002, taking and pooling 12 cores $(2.5 \mathrm{~cm}$ in diameter $)$ from each plot. We measured soil microfauna (nematodes, enchytraeids), net $\mathrm{N}$ mineralization, total $\mathrm{C}$, total $\mathrm{N}$, total $\mathrm{P}, \mathrm{pH}$, Olsen $\mathrm{P}$, soil and water content, as well as seasonal herbage accumulation. Herbage net accumulation was measured at each site in three 0.5 $\mathrm{m}^{2}$ exclusion cages, with pre-trimming in October and cutting after 55 days. All da ta are reported on an ovendry basis (Blakemore et al. 1987). Microbial C, N and $\mathrm{P}$ were measured by fumigation-extraction procedures; the k-factors used for converting extractable $\mathrm{C}, \mathrm{N}$ and $\mathrm{P}$ flush to microbial $\mathrm{C}, \mathrm{N}$ and $\mathrm{P}$ were respectively 0.41 (Sparling et al. 2000), 0.45 (Jenkinson 1988) and 0.40 (Brookes et al. 1982). We measured net $\mathrm{N}$ mineralization by incubating $5.0 \mathrm{~g}$ of mineral soil at $60 \%$ of water-holding capacity in $125-\mathrm{ml}$ polypropylene cups for 56 days at $25^{\circ} \mathrm{C}$ ( $\mathrm{Scott}$ et al. 1998). Mineral-N (ammonium-N and nitrate$\mathrm{N})$ was measured at 0 and 56 days by extracting the samples with $50 \mathrm{~mL}$ of $2 \mathrm{M} \mathrm{KCl}$, shaking for 1 hour, then filtering. Extractable ammonium-N and nitrate$\mathrm{N}$ were measured colourimetrically with a Lachat Quickchem FIA800 analyzer. Net N mineralization was calculated as the difference in ammonium- $\mathrm{N}$ and nitrate-N values at 0 and 56 days. Soil microfauna were extracted by the tray method; populations are given on a $\mathrm{m}^{2}$ basis for $0-7.5 \mathrm{~cm}$ soil depth.

We compared soil net $\mathrm{N}$ mineralization and herbage accumulation in October and November 2002, and related them to soil properties using regression analyses under procedure MGLH in SYSTAT.

\section{Results and discussion}

Some properties of the soils $(0-7.5 \mathrm{~cm}$ depth) that had developed under the ecological gradient are shown in Table 1. Although soil $\mathrm{C}$ values were in a fairly narrow range (42 to $63 \mathrm{~g} / \mathrm{kg}$ ), Olsen $\mathrm{P}$ and net $\mathrm{N}$ mineralization covered a wider range of values.

Across all sites herbage accumulation in spring was
Figure 1 Relationship between herbage dry matter and net $\mathrm{N}$ mineralization for $0-7.5 \mathrm{~cm}$ soil $\left(56\right.$ days at $\left.25^{\circ} \mathrm{C}\right)$. Error bars are SEM. The organic sites are numbered (see Table 1).

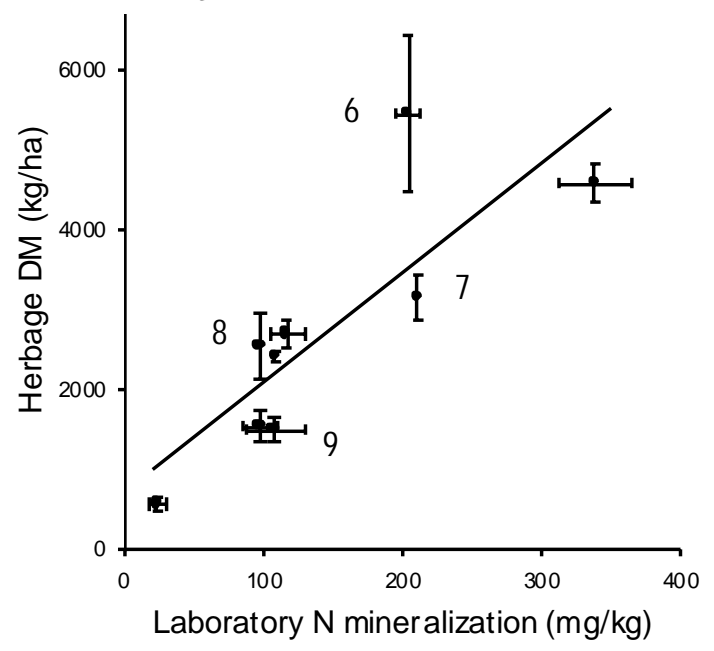

Figure 2 Relationship between herbage $\mathrm{N}$ and $\mathrm{N}$ mineralization for $0-7.5 \mathrm{~cm}$ soil ( 56 days at $\left.25^{\circ} \mathrm{C}\right)$. Error bars are SEM.

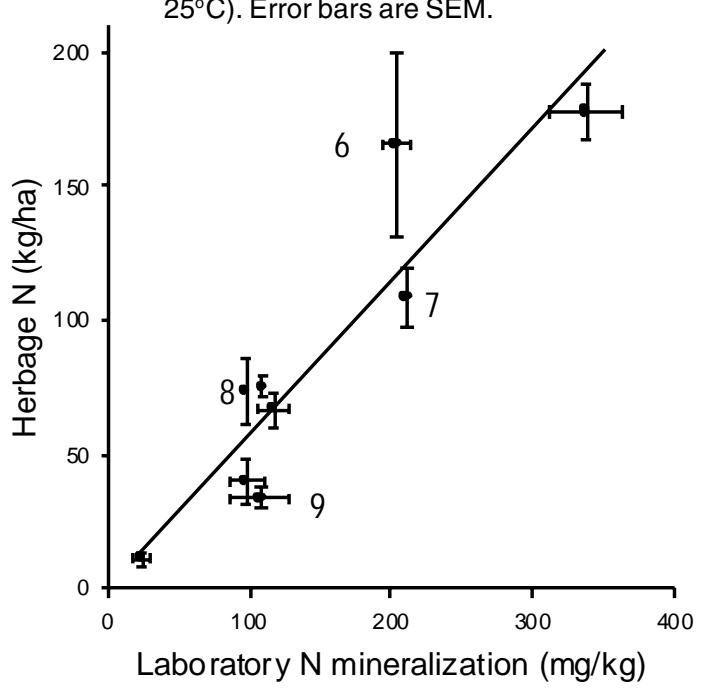

related to soil net $\mathrm{N}$ mineralization $\left(\mathrm{r}^{2}=0.68, \mathrm{P}<0.01\right)$ (Figure 1). This is consistent with pastures in New Zealand generally responding to an increase in available soil nitrogen. Herbage $\mathrm{N}$ at all sites in spring was even more strongly related to soil net $\mathrm{N}$ mineralization $\left(\mathrm{r}^{2}=0.84, \mathrm{P}<0.001\right)$ (Figure 2). This suggests pasture roots are able to access mineral $\mathrm{N}$ produced from the same pool of $\mathrm{N}$ as that released in the laboratory incubation, and the plants then translocate this $\mathrm{N}$ to the leaves.

Herbage accumulation was negatively and strongly related to the soil $\mathrm{C}: \mathrm{N}$ ratio $\left(\mathrm{r}^{2}=0.78, \mathrm{P}<0.002\right)$ (Figure 3 ). The $\mathrm{C}: \mathrm{N}$ ratio gives an indication of the $\mathrm{N}$ quality 
Figure 3 Relationship between herbage accumulation and soil C:N for $0-7.5 \mathrm{~cm}$ soil. Error bars are SEM.

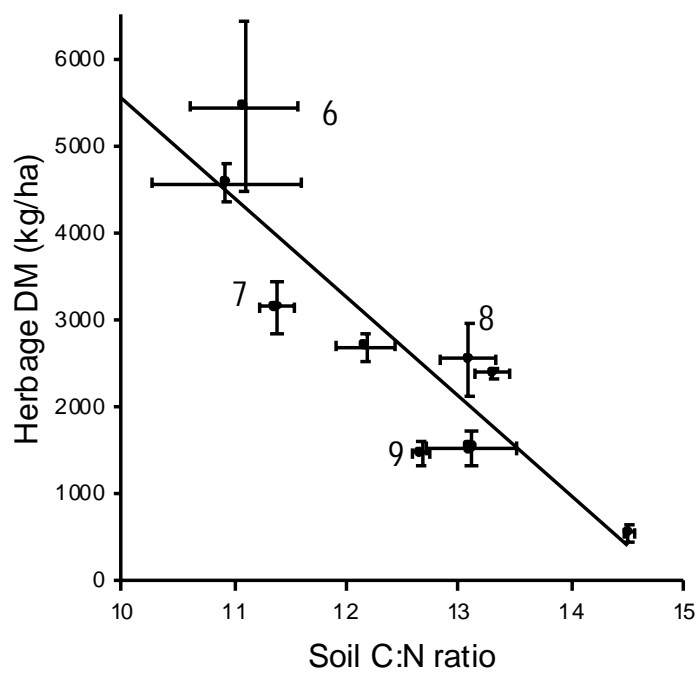

Figure 4 Relationship between herbage accumulation and soil $\mathrm{N}$ for $0-7.5 \mathrm{~cm}$ soil. Error bars are SEM.

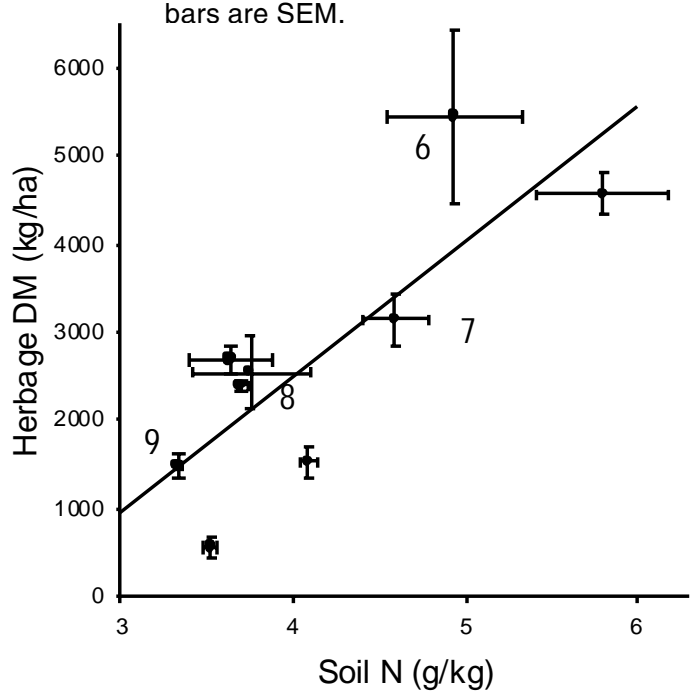

of the soil organic matter; a high ratio shows low $\mathrm{N}$ quality and a low ratio shows high $\mathrm{N}$ quality. The $\mathrm{N}$ released (mineralized) by these soils was also negatively related to the $\mathrm{C}: \mathrm{N}$ ratio $\left(\mathrm{r}^{2}=0.75, \mathrm{P}<0.003\right)$. Herbage accumulation was less strongly related to soil total $\mathrm{N}\left(\mathrm{r}^{2}=0.66, \mathrm{P}<0.01\right)$ (Figure 4$)$, suggesting that this measure of the quantity of soil $\mathrm{N}$ was here somewhat less important than its quality.

The $\mathrm{N}$ released (mineralized) by these soils was most strongly related to soil microbial-P $\left(r^{2}=0.94\right.$, $\mathrm{P}=0.001$ ) (Table 2), which was in turn weakly related to Olsen $\mathrm{P}\left(\mathrm{r}^{2}=0.51\right)$. Site 3 , however, was an outlier with relatively low $\mathrm{N}$ status and high $\mathrm{P}$ status (Table 1). When this data point was removed the relationship between soil microbial-P and Olsen $\mathrm{P}$ was much stronger $\left(\mathrm{r}^{2}=0.93, \mathrm{P}=0.001\right)$. Further work is needed to confirm these relationships at different seasons and, if validated, to explain the mechanisms responsible. Other factors that were correlated with herbage accumulation were nematode abundance (Table 2) and soil $\mathrm{pH}$ (the multiple regression was $\mathrm{r}^{2}$ $=0.90, \mathrm{P}<0.02)$. The relationships between either herbage accumulation or net $\mathrm{N}$ mineralization and microbial biomass $\mathrm{C}$ or $\mathrm{N}$ were not significant.

The over-riding factor influencing $\mathrm{N}$ supply at Ballantrae in spring 2002, appeared to be the quality (C:N ratio) of soil organic matter in the topsoils. Quality would have been enhanced at those sites with greater growth of legumes over the last 15 years or more, that in turn would have depended on the P status of the soil (Table 1). Site 3 is an outlier in the data set and when this is removed there are also strong relationships between Olsen $\mathrm{P}$ and both herbage accumulation and herbage $\mathrm{N}$. The soil parent material at two sites (1996 organic farmlets) is calcareous mudstone that has a high $\mathrm{P}$ status. This may explain some differences in site $\mathrm{P}$ status, and thence $\mathrm{N}$ status (Table 1), that cannot be explained by fertiliser applications. The relationship between the quality of organic matter and microbial net $\mathrm{N}$

Table 2 Nematode numbers, enchytraeid numbers, microbial biomass $C, N$ and $P$ of the soils $(0-7.5 \mathrm{~cm})$ sampled in October 2002.

\begin{tabular}{lccccc}
\hline Site & $\begin{array}{c}\text { Total } \\
\text { nematodes } \\
\left(\text { million/m } / \mathrm{m}^{2)}\right.\end{array}$ & $\begin{array}{c}\text { Total } \\
\text { enchytraeids } \\
\text { (thousand/m })\end{array}$ & $\begin{array}{c}\text { Microbe } \\
\text { C } \\
(\mathrm{mg} / \mathrm{kg})\end{array}$ & $\begin{array}{c}\text { Microbe } \\
\mathrm{N}\end{array}$ & $\begin{array}{c}\text { Microbe } \\
\mathrm{P}\end{array}$ \\
\hline 1. No P farmlet & 2.3 & 13 & 1862 & 261 & 61 \\
2. Medium P farmlet & 2.7 & 6 & 1991 & 294 & 99 \\
3. High P farmlet & 4.9 & 105 & 1531 & 266 & 96 \\
4. Bulls + N farmlet & 2.9 & 27 & 129 & 338 & 161 \\
5. Bulls farmlet & 4.8 & 20 & 1434 & 218 & 99 \\
6. Organic 1996 low stocked & 5.5 & 38 & 1672 & 283 & 123 \\
7. Organic 1996 high stocked & 3.9 & 33 & 1399 & 219 & 130 \\
8. Organic 1985 low stocked & 4.2 & 46 & 1430 & 229 & 76 \\
9. Organic 1985 high stocked & 3.5 & 11 & & 83 \\
\hline
\end{tabular}


mineralization in the 4 farmlets that had organic management appeared to be on the same trend-lines as those in the conventional farmlets, indicating that the underlying net $\mathrm{N}$ mineralization process was similar under conventional and organic management. This is consistent with recent work in the UK (Stockdale et al. 2002).

\section{Conclusions}

The results showed that differences in herbage accumulation in spring were controlled mainly by the quality of the soil organic matter and, in particular, the C:N ratio. This in turn was largely related to the $\mathrm{P}$ status of the soil. Some parts of the landscape had high quality soil organic matter that seemed to be related more to inherent properties of the landscape (e.g., $\mathrm{P}$ in the mudstone), than to management. The productivity and ecosystem functions of the soils under organic management were within the range of soils under conventional treatments. We have too few data at this stage to determine which groups of soil organisms dominated control of $\mathrm{N}$ supply to herbage, although the release of $\mathrm{N}$ from soil to plant roots did appear to be related to some degree to microbial $\mathrm{P}$ and nematode abundance.

\section{REFERENCES}

Barker, D.J.; Shepherd, D.G.; Mackay, A.D.; Dymock, N. 1999. Hill country investment options. Cocksfoot pasture vs. Superphosphate fertiliser. Proceedings of the New Zealand Grasslands Association 61: 17-21.

Blakemore, L.C.; Searle, P.L.; Daly, B.K. 1987.
Methods for chemical analysis of soils. Department of Scientific and Industrial Research, New Zealand Soil Bureau Scientific Report No. 80.

Brookes, P.C.; Powlson, D.S.; Jenkinson, D.S. 1982. Measurement of microbial biomass phosphorus in soil. Soil Biology and Biochemistry 14: 319-329.

Jenkinson, D.S. 1988. Determination of microbial biomass carbon and nitrogen in soils. pp. 368-386. In: Advances in nitrogen cycling in agricultural ecosystems. Ed. Wilson J.R. CAB Intemational, UK. Lambert, M.G.; Clark, D. A.; Mackay, A.D.; Costall, D.A. 2000. Effects of fertiliser application on nutrient status and organic matter content of hill soils. New Zealand Journal of Agricultural Research 43: 127-138.

Mackay, A.D.; Betteridge, K.; Devantier, B.J.; Budding, P.J.; Niezen, J.H. 1998. Chemical-free hill country sheep and beef livestock production systems. Proceedings of the New Zealand Grassland Association 60: 15-18.

Scott, N.A.; Parfitt, R.L.; Ross, D.J.; Salt, G.J. 1998. Carbon and nitrogen transformations in New Zealand plantation forest soils from sites with different N status. Canadian Journal of Forest Research 28: 967-976.

Sparling, G.P; Shepherd, T.G.; Schipper, L.A. 2000. Topsoil characteristics of three contrasting New Zealand soils under four long-term land uses. New Zealand Journal of Agricultural Research 43: 569583.

Stockdale, E.A.; Shepherd, M.A.; Fortune, S.; Cuttle, S.P. 2002. Soil fertility in organic farming systems - fundamentally different? Soil Use and Management 18: 301-308. 